\title{
Co-infections with bovine herpesvirus type 5 and bovine viral diarrhoea virus
}

\author{
[Co-infecções pelo herpesvírus bovino tipo 5 e vírus da diarréia viral bovina]
}

\author{
F.R. Spilki $i^{1,5}$, T.C. Silva ${ }^{2,4}$, P.A. Esteves ${ }^{2,4}$, M.B. Teixeira ${ }^{2,4}$, H.B.C.R. Batista ${ }^{2,4}$, \\ C. Chiminazzo ${ }^{2,4}$, D. Driemeier ${ }^{3}$, A.C. Franco ${ }^{2,4}$ P.M. Roehe Pr, $^{2,4}$ \\ ${ }^{1}$ Laboratório de Virologia - UNICAMP \\ Caixa postal 6109 \\ 13083-971-Campinas, SP \\ ${ }^{2}$ Departamento de Microbiologia - UFRGS - Porto Alegre, RS \\ ${ }^{3}$ Departamento de Patologia Clínica Veterinária - UFRGS - Porto Alegre, RS \\ ${ }^{4}$ Centro de Pesquisa Veterinária Desidério Finamor - Eldorado do Sul, RS \\ ${ }^{5}$ Bolsista do $\mathrm{CNPq}$
}

\begin{abstract}
During a series of experiments attempting to reproduce clinically apparent bovine herpesvirus type 5 (BoHV-5) infections, a group of calves was inadvertently infected with bovine viral diarrhoea virus (BVDV). Another group of calves was infected with BoHV-5 only. This paper reports the outcome of such infections. Two out of six calves solely infected with BoHV-5 displayed moderate to severe clinical signs. Three out of four calves of the group co-infected with BoHV-5 and BVDV developed severe clinical signs, two of them died. BoHV-5 virus was isolated to higher titres and for a longer period from the group of calves infected with both viruses. These results suggest that BVDV may enhance clinical signs induced by BoHV-5 and may also play a role in extending the period of BoHV-5 shedding.
\end{abstract}

Keywords: BoHV-5, BVDV, co-infection, experimental inoculation

\section{RESUMO}

Durante a realização de experimentos envolvendo inoculações experimentais com herpesvírus bovino tipo 5 (BoHV-5), um grupo de bovinos foi acidentalmente também inoculado com vírus da diarréia viral bovina (BVDV). Os dados obtidos nesta co-infecção foram então comparados a aqueles observados em animais inoculados exclusivamente com BoHV-5. No grupo infectado com BoHV-5 somente, dois dos seis animais inoculados mostraram sinais clínicos de moderados a graves. No grupo co-infectado com BoHV5 e BVDV, três dos quatro animais desenvolveram doença grave, e dois deles morreram. BoHV-5 foi isolado em títulos maiores e por um período de tempo mais longo no grupo co-infectado. Os resultados sugerem que o BVDV pode exacerbar os sinais clínicos induzidos pelo BoHV-5 e, ainda, aumentou os níveis de excreção deste último.

Palavras-chave: BoHV-5, BVDV, co-infecção, inoculação experimental

Recebido em 10 de setembro de 2004

Aceito em 19 de dezembro de 2005

E-mail: spiki@unicamp.br

Apoio: CNPq, PRONEX, FAPERGS 


\section{INTRODUCTION}

Bovine herpesvirus type 5 (BoHV-5), a member of Alphaherpesvirinae subfamily of the family Herpesviridae, is the causative agent of bovine herpesvirus encephalitis (Meyer et al., 2001), a condition characterized by encephalitis or nonsuppurative meningoencephalitis (Bagust and Clark, 1972; Carrillo et al., 1983). The disease usually affects cattle up to two years old, although occasionally older animals may be involved (Salvador et al., 1998). When clinical signs are apparent, mortality rates usually reach $100 \%$, particularly in young animals (Bagust and Clark, 1972). In Brazil, an increasing number of documented cases of BoHV-5 encephalitis has been observed, particularly in Pantanal region (Southern Amazonia), in cattle farming regions around the Amazon Tropical Rain Forest (states of Mato Grosso do Sul and Mato Grosso) and in Rio Grande do Sul state (Riet-Correa et al., 1989; Salvador et al., 1998). In spite of that, the majority of cases of BoHV-5 encephalitis in Brazil is likely undiagnosed or misdiagnosed as rabies, $\mathrm{NaCl}$ intoxication and botulism (D'Offay et al., 1993; Salvador et al., 1998).

Bovine viral diarrhoea virus (BVDV), a member of the Pestivirus genus of the family Flaviridae, has been linked to a number of clinical conditions of cattle, including diarrhoea, abortions, congenital abnormalities and birth of persistently infected animals (Nettleton and Entrican, 1995). Most acute BVDV infections in postnatal life are generally inapparent or run a subclinical course (Ames, 1986). BVDV can cause severe immunossupression, following acute, persistent or subclinical infections. The immunossupression is associated with transient leucopenia, neutrophil disfunction and other immunological disturbances such as apoptosis of peripheral blood mononuclear cells (Coria et al., 1983; Lambot et al., 1988). This immunossupressive effect appears to impair the ability of the animal to clear virus or bacteria from its blood and tissues. Regarding bovine herpesvirus type 1 (BoHV-1), it was shown that this virus could be recovered from more tissues and to higher titres from calves first given BVDV than from calves inoculated with BoHV1 only (Potgieter et al., 1984). Other authors, however, did not succeed in attempting to reactivate latent $\mathrm{BoHV}-1$ infections from three calves after inoculation with a mixture of nine cytopathic strains of BVDV (Edwards and Roeder, 1983).

The pathogenesis of BoHV-5 infections is not completely known, yet (Belknap et al., 1994; Perez et al., 2002). Contamination with BoHV-5 probably occurs early in life, since the disease is usually manifested in young animals (Salvador et al., 1998). BoHV-5 experimental inoculations in calves are usually difficult to reproduce with overt clinically apparent, severe neurological disease (Cascio et al., 1999; Perez et al., 2002). During experiments involving the inoculation of calves with BoHV-5, a group of calves was inadvertently inoculated with BVDV, which was later found as a cell culture contaminant. In this study, the clinical, pathological and virological consequences of infecting calves with BoHV-5 or BoHV-5 associated to BVDV are presented and discussed.

\section{MATERIALS AND METHODS}

BoHV-5 was multiplied in Madin Darby bovine kidney cells (MDBK, ATCC CCL-22) or CRIB-1 cells (cell resistant to BVDV infection; Flores and Donis, 1995). With the exception of the batch of MDBK cells which was later found contaminated with BVDV, all other cell cultures were tested to ensure the absence of BVDV and bovine herpesviruses (BoHV) by an immunoperoxidase assay (IPMA) (Roehe et al., 1994; Oliveira et al., 1996). Cells were multiplied in Eagle's minimal essential medium (MEM), supplemented with 6\% BVDV- and BoHV-free fetal calf serum (FCS; Nutricell) and $10 \mu \mathrm{g} / \mathrm{ml}$ enrofloxacin. The BVDV used for coinfection of calves was an accidental contaminant of such a batch of MDBK cells. The virus was isolated and characterised as a BVDV type I virus with the aid of a panel of monoclonal antibodies to BVDV antigens (Oliveira et al., 1996). Cytopathic BVDV strain Singer (Coria and McClurkin, 1978) was used for neutralization assays.

BoHV-5 strain EVI-88/95 was used for animal inoculations (Souza et al; 2002). This virus is highly pathogenic for 3 to 4 month-old, naive calves (not shown). The viruses were multiplied in MDBK or CRIB-1 and harvested when the cytopathic effect (CPE) was evident in $90 \%$ to 
$100 \%$ of the monolayers. Stocks were prepared following standard procedures (Roehe et al., 1997) and stored at $-70{ }^{\circ} \mathrm{C}$. All procedures for BoHV-5 isolation, multiplication, quantitation and measurement of antibodies in secretions, as well as BVDV isolation attempts, were performed on MDBK cells BVDV- and BoHVfree by IPMA.

Twelve mixed european breeds beef calves aging 5 month-old were used for the inoculations. Their serological and virological status to BoHV5 and BVDV was determined. All calves were negative for antibodies to BoHV-5 and BVDV in the beginning of the experiment. The animals were housed in separate groups. Group $1(n=6)$ was only inoculated with BoHV-5; group 2 ( $\mathrm{n}=$ 4), was inoculated with BoHV-5 and BVDV. The remainder two calves were inoculated with sterile culture medium and kept as uninfected controls. Calves were inoculated with $10^{8.8} 50 \%$ tissue culture infective doses $\left(\mathrm{TCID}_{50}\right)$ of BoHV-5 EVI-88/95. Calves of group 1 received a BVDV-free BoHV-5 inoculum; calves of group 2 received the same amount of BoHV-5, but from a BVDV-contaminated preparation. Each calf was intranasally inoculated with a volume of $8 \mathrm{ml}$ of the virus suspension, $4 \mathrm{ml}$ into each nostril. Clinical evaluation and collection of samples from nasal and ocular secretions were carried out every other day up to day 21 post infection (PI). Blood samples were collected on days $0,7,15$ and 21PI. The control calves were kept in separate facilities and were subjected to identical protocols of observation and sampling. All surviving calves were culled on day $21 \mathrm{PI}$ and were submitted to necropsy and histopathological examinations.

Calves were necropsied soon after death or culled in extremis and tissues were sampled at necropsy. Samples were fixed in $10 \%$ buffered formalin, processed and stained with hematoxylin-eosin following routine procedures.

Nasal secretions were daily collected until day 21PI with sterile cotton swabs deeply introduced into each nostril. After sampling, swabs were dipped in $2 \mathrm{ml}$ of MEM supplemented with $100 \mu \mathrm{g} / \mathrm{ml}$ enrofloxacin and $2.5 \mu \mathrm{g} / \mathrm{m}$ amphotericin B (MEM AB 10X) and incubated overnight at $4^{\circ} \mathrm{C}$. Subsequently, the swabs were discarded and the supernatant stored at $-70^{\circ} \mathrm{C}$ for further processing. Inoculation of cell cultures followed standard procedures. Briefly, $10^{-1}$ to $10^{-7}$ dilutions of the initial suspensions were prepared and inoculated onto MDBK cells and incubated at $37^{\circ} \mathrm{C}$, in $5 \% \mathrm{CO}_{2}$ atmosphere. Solid tissues (spleen, liver, adrenal glands, thymus, trachea, lungs, trigeminal ganglia, and various lymph nodes), brain specimens (frontal cortex, pons, cerebellum, hippocampus, medulla, and cortex) and cerebrospinal fluid (CSF) were collected from the two necropsied calves. Suspensions of tissues (approximately 10\% w/v) were prepared in MEM AB 10X, clarified by centrifugation and the supernatant was inoculated onto CRIB-1 monolayers (Flores and Donis, 1995). After $1 \mathrm{~h}$ for adsorption at $37^{\circ} \mathrm{C}$, the inoculum was removed, cells were washed three times with MEM AB 10X and were overlaid with the same medium. Cells were daily monitored for cytopathic effect (CPE).

Isolation of BVDV was performed from fragments of lymph nodes and spleens of inoculated animals. The inoculi, prepared as above, were mixed with an anti-BoHV-5 hyperimmune serum (prepared in rabbits) to a final concentration of $10 \%$. After $1 \mathrm{~h}$ of incubation at $37^{\circ} \mathrm{C}$, the suspensions were inoculated onto freshly prepared BVDV-free MDBK monolayers. After five days of incubation at $37^{\circ} \mathrm{C}$, cells were fixed and stained by immunoperoxidase using an anti-BVDV monoclonal antibody (Mab 112; Paton et al., 1991).

The varying serum-constant virus neutralization method was performed as described by House and Baker (1971) and modified as the following: twofold dilutions $(1 / 2$ to $1 / 128)$ of sera to be tested were prepared in quadruplicate in 96 well microtitre plates. An equal volume $(50 \mu \mathrm{l} /$ well $)$ containing $100 \mathrm{TCID}_{50}$ of the appropriate virus (BoHV-5 EVI 88/95 or BVDV Singer) was added to each well. Each virus was added in completely independent tests, in previously UVsterilised laminar flow cabinets, to minimize chances of cross- contamination. The mixtures were incubated at $37^{\circ} \mathrm{C}$ for $1 \mathrm{~h}$. Fifty microlitres of a cell suspension containing $1.5-3 \times 10^{4}$ cells were, then, added to each well and incubated at $37^{\circ} \mathrm{C}$, in $5 \% \mathrm{CO}_{2}$ atmosphere. Readings were performed daily, 24, 48, 72, 96 and 120h PI, searching for the characteristic CPE. 
Analysis of variance was used and the least significant difference at $\mathrm{P}<0.05$ was determined. Comparisons were made within the groups from day to day and comparisons were made between the groups. Statistical analysis was performed using Minitab $^{\mathrm{TM}}$ for Windows Release 11.1 (User's..., 1996).

\section{RESULTS}

The clinical signs detected in calves of all groups are shown in Table 1. Four out of six calves from group inoculated with BoHV-5 had only mild signs of nervous impairment, such as apathy, anorexia and a slight incoordination. Two other calves were severely affected. One of them (calf no. 1) developed hypersalivation, incoordination, and inability to stand from day 9 PI onwards; these signs lasted for a week, when the calf fully recovered. Another calf (calf no. 2), on day 7 PI, presented signs similar to those described before albeit more severe, including proprioceptive deficit (characterized by bizarre standing positions and head deviations, teeth grinding and tongue paralysis). On day $14 \mathrm{PI}$, the signs progressed to complete recumbency and stupor, when the calf was culled.

All the calves infected with BoHV-5 and BVDV, presented light fever around the fourth day PI. Two of them displayed signs of severe neurological impairment (apathy, loss of appetite, incoordination, tongue paralysis, teeth grinding, hypersalivation, blindness, seizures, coma and death). One of such calves (calf A) died on day 13 PI, about 12 hours after the appearance of the first signs. Calf B, by day 14 PI showed signs of neurological impairment (apathy, incoordination, teeth grinding and inability to swallow), but gradually recovered and, after 10 days of illness, it presented no clinically noticeable sign. Calf $\mathrm{C}$, showed similar signs (although more intense) to those displayed by calf $\mathrm{B}$, remained ill for 7 days and was culled in extremis on day 16 PI. Calf D did not display any sign of encephalitis. From the third day PI, nasal secretions (sero-mucous, mucous ou mucohaemorragic) in moderate to abundant volumes could be observed on the three calves that displayed signs of disease (A, B and C). Nasal secretions and other signs of respiratory disease were prominent. No clinical sign suggestive of BVDV infection was observed, but a mild diarrhoea in calves $\mathrm{A}$ and $\mathrm{C}$.

No clinical sign was observed in control group calves throughout the experiment.

At necropsy, despite the clinical signs presented, all calves only infected with BoHV-5 had small areas of malacia, particularly on the frontal and temporal lobes of the cortex. Mild pneumonia was observed in the lungs of one calf that died on day 14 PI. Such pneumonia was associated to the presence of mucus in the tracheal lumen. Histopathological examinations revealed diffuse mononuclear meningoencephalitis, perivascular cuffing associated to foci of malacia, foamy macrophages and marked neuronophagia. Periarteriolar edema was also found on vessels from the subcortical layer. In some animals, inclusion bodies were detected in cortical neurons and astrocytes. Intense ganglioneuritis in the trigeminal ganglia (TG) was a consistent finding in all animals.

At necropsy, the two calves that died on days 13 and 16 PI (respectively, calves A and C) showed a marked lymphadenopathy affecting particularly the retropharyngeal, cervical superficial and mediastinic lymph nodes. The lungs showed signs of light to moderate pneumonia. Microscopically, congestion and foci of bacterial pneumonia were evident. Mucus was evident in the tracheal lumen. In the left frontal cortex, discrete areas of malacia were present. Intranuclear inclusions were evident within the astrocytes, particularly in areas of multifocal encephalitis, where lymphocyte infiltration was most intense. The trigeminal ganglia showed typical ganglioneuritis. In calf $\mathrm{C}$ (culled on day $16 \mathrm{PI}$ ), rumenitis in the cardial region was present. The brain showed signs of focal encephalitis, congestion and intense multifocal, non-uniform malacia affecting the frontal left as well as the pyriform lobes. At histopathological exam, perivascular cuffing of irregular distribution associated to foci of malacia were present. Another consistent finding was periarteriolar oedema. A large number of foamy macrophages and neuronophagia were also evident. The spleen showed a marked follicular hyperplasia. 
Co-infections with bovine herpesvirus type $5 .$.

Table 1. Clinical signs observed in calves infected with BoHV-5 (group 1) or co-infected with BoHV-5 and BVDV (group 2)

\begin{tabular}{|c|c|c|c|c|c|c|c|c|c|c|c|c|c|}
\hline \multirow{2}{*}{$\begin{array}{l}\text { Animal \# } \\
\text { Group } 1\end{array}$} & \multirow[b]{2}{*}{$\begin{array}{c}\text { Day of onset } \\
\text { of clinical } \\
\text { signs }\end{array}$} & \multirow[b]{2}{*}{ Clinical sign } & \multicolumn{11}{|c|}{ Nervous sign } \\
\hline & & & Apathy & Dysphagia & $\begin{array}{l}\text { Teeth } \\
\text { cheewing }\end{array}$ & $\begin{array}{c}\text { Pressing } \\
\text { head against } \\
\text { walls } \\
\end{array}$ & Hypersalivation & $\begin{array}{c}\text { Tongue } \\
\text { paralysis }\end{array}$ & Hypermetry & Incoordination & $\begin{array}{l}\text { Walk in } \\
\text { circles }\end{array}$ & $\begin{array}{l}\text { Transient } \\
\text { blindness }\end{array}$ & Death \\
\hline 1 & 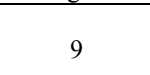 & $\begin{array}{l}\text { Muco-haemorrhagic } \\
\text { nasal secretion }\end{array}$ & ++ & ++ & + & 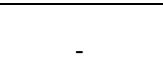 & ++ & + & - & ++ & - & - & - \\
\hline 2 & 7 & $\begin{array}{c}\text { Mucous nasal secretion, } \\
\text { coughing }\end{array}$ & +++ & ++ & +++ & +++ & +++ & ++ & + & +++ & - & + & + \\
\hline 3 & - & $\begin{array}{c}\text { Serous nasal discharge, } \\
\text { coughing }\end{array}$ & + & - & - & - & - & - & - & - & - & - & - \\
\hline 4 & - & Serous nasal discharge & - & - & - & - & - & - & - & - & - & - & - \\
\hline 5 & - & Coughing & + & - & - & - & - & - & - & - & - & - & - \\
\hline 6 & - & Mucous nasal discharge & + & - & - & - & - & - & + & + & - & - & - \\
\hline \multicolumn{14}{|l|}{ Group 2 } \\
\hline A & 13 dpi & $\begin{array}{l}\text { Muco-haemorrhagic } \\
\text { nasal secretion, } \\
\text { dyspnoea }\end{array}$ & + & - & + & - & + & - & + & +++ & +++ & ++ & + \\
\hline B & - & Light fever & - & - & - & - & - & - & - & - & - & - & - \\
\hline $\mathrm{C}$ & 9 dpi & $\begin{array}{l}\text { Fever, anorexia, muco- } \\
\text { haemorrhagic nasal } \\
\text { secretion, dyspnoea }\end{array}$ & +++ & +++ & ++ & +++ & ++ & +++ & +++ & +++ & - & +++ & + \\
\hline $\mathrm{D}$ & $14 \mathrm{dpi}$ & $\begin{array}{l}\text { Fever, mucous nasal } \\
\text { secretion, dyspnoea }\end{array}$ & ++ & +++ & +++ & + & +++ & ++ & + & ++ & - & ++ & $\mathrm{R}$ \\
\hline
\end{tabular}

Signals of nervous impairment: (-) unavailable; $(+)$ mild; $(++)$ moderate; $(+++)$ severe; $\mathrm{R}=$ spontaneous recovery 
The trigeminal ganglia showed intense ganglioneuritis. Severe vasculitis was detected in numerous areas of the CNS in necropsied calves, with oedema and perivascular cuffing around the arterioles.

Calf B, which developed clinical signs but recovered from the disease, was kept alive until day 180 PI, when it was culled and submitted to post mortem examinations. Large atrophic lesions were evident in the left frontal lobe of the cortex. A large lesion was found within the occipital lobe, resembling scarring tissue in appearance, with a cutting surface resembling foci of malacia. At histopathological exam, focal malacia was evident, with areas of the frontal cortex infiltrated by plasma cells and small foci of malacia in the trigeminal ganglia. Calves A and $\mathrm{C}$ also presented rumenitis, petechial and suffusive haemorrhagic lesions along the abdominal serosae. The fourth animal of this group had no evident macroscopical lesions in any of its organs.

The two uninfected control calves had no noticeable lesions in any of its organs.
No neutralizing antibodies to BoHV-5 and BVDV were detected in animals on day 0 PI. Calves infected with BoHV-5 only developed detectable neutralizing antibody responses from day 7 PI onwards. No neutralizing antibodies to BVDV were detected in calves of this group. In calves infected with BoHV-5 and BVDV, neutralizing antibodies to both BoHV-5 and BVDV were detected from day 7 PI onwards. No neutralizing antibodies to either BoHV-5 or BVDV were detected in calves of the control group.

BoHV-5 was isolated from the brain, trachea, lungs and adrenal glands to titres ranging from $<10^{0.5}$ to $10^{3}$ TCID $_{50} / 50 \mu 1$ (Table 2 ). No virus was detected in any organs collected from animals culled on day $21 \mathrm{PI}$. In the group coinfected with BoHV-5 and BVDV, BoHV-5 excretion started at day $1 \mathrm{PI}$ and decreased to undetectable levels on day 19 PI; infectious virus titres were detected between days 5 and $11 \mathrm{PI}$, with peak titres of up to $10^{5} \mathrm{TCID}_{50} / 50 \mu \mathrm{l}$. Viral excretion by calves of the group infected with BoHV-5 only started on day 1 PI and persisted up to day 13 PI.; the peak of infectious virus excretion was observed on day 6 PI (Fig. 1).

Table 2. Infectious BoHV-5 titres in organs of calves infected with BoHV-5 or co-infected with BVDV and BoHV-5

\begin{tabular}{|c|c|c|c|c|c|c|c|c|c|c|}
\hline \multirow{2}{*}{ Organ } & \multicolumn{6}{|c|}{ BoHV-5 } & \multicolumn{4}{|c|}{ BoHV-5 + BVDV } \\
\hline & 1 & 2 & 3 & 4 & 5 & 6 & A & $\mathrm{B}$ & $\mathrm{C}$ & $\mathrm{D}$ \\
\hline Frontal Cortex & $2 *$ & 2.5 & $<0.5$ & $<0.5$ & $<0.5$ & $<0.5$ & 3 & $<0.5$ & 2.5 & $<0.5$ \\
\hline Pons & 1 & 2 & $<0.5$ & $<0.5$ & $<0.5$ & $<0.5$ & 1 & $<0.5$ & 1.5 & $<0.5$ \\
\hline Hipocampus & 1 & 2 & $<0.5$ & $<0.5$ & $<0.5$ & $\mathrm{nc}$ & 1.25 & $<0.5$ & 1.5 & $<0.5$ \\
\hline Cerebellum & $<0.5$ & $<0.5$ & $<0.5$ & $<0.5$ & $<0.5$ & $<0.5$ & 2.5 & $<0.5$ & 2.0 & $<0.5$ \\
\hline Spinal cord & $<0.5$ & $<0.5$ & $<0.5$ & $<0.5$ & $<0.5$ & $<0.5$ & 1.5 & $<0.5$ & 0.5 & $<0.5$ \\
\hline Trigeminal ganglia & $<0.5$ & 1.5 & $<0.5$ & $<0.5$ & $<0.5$ & $<0.5$ & 0.25 & $<0.5$ & $\mathrm{Nc}$ & $<0.5$ \\
\hline LCR & $<0.5$ & $<0.5$ & $<0.5$ & $<0.5$ & $<0.5$ & $<0.5$ & $<0.5$ & $<0.5$ & $<0.5$ & $<0.5$ \\
\hline Liver & $<0.5$ & $<0.5$ & $<0.5$ & $<0.5$ & $<0.5$ & $<0.5$ & 2.5 & $<0.5$ & 2.5 & $<0.5$ \\
\hline Adrenal glands & $<0.5$ & $<0.5$ & $<0.5$ & $<0.5$ & $<0.5$ & $<0.5$ & 1.25 & $<0.5$ & 1.25 & $<0.5$ \\
\hline Thymus & $<0.5$ & $<0.5$ & $<0.5$ & $<0.5$ & $<0.5$ & $<0.5$ & $\mathrm{nc}$ & $<0.5$ & $<0.5$ & $<0.5$ \\
\hline $\begin{array}{l}\text { Retropharyngeal } \\
\text { lymphnodes }\end{array}$ & $<0.5$ & $<0.5$ & $<0.5$ & $<0.5$ & $<0.5$ & $<0.5$ & $<0.5$ & $<0.5$ & $<0.5$ & $<0.5$ \\
\hline $\begin{array}{l}\text { Haemolymphatic } \\
\text { nodes }\end{array}$ & $<0.5$ & $<0.5$ & $<0.5$ & $<0.5$ & $<0.5$ & $<0.5$ & 1.25 & $<0.5$ & $<0.5$ & $<0.5$ \\
\hline $\begin{array}{l}\text { Mediastinic } \\
\text { lymphnodes }\end{array}$ & $<0.5$ & $<0.5$ & $<0.5$ & $<0.5$ & $<0.5$ & $<0.5$ & 1.0 & $<0.5$ & $<0.5$ & $<0.5$ \\
\hline Spleen & $<0.5$ & $<0.5$ & $<0.5$ & $<0.5$ & $<0.5$ & $<0.5$ & 2.5 & $<0.5$ & 2.25 & $<0.5$ \\
\hline Trachea & $<0.5$ & $<0.5$ & $<0.5$ & $<0.5$ & $<0.5$ & $<0.5$ & 0.75 & $<0.5$ & 1.0 & $<0.5$ \\
\hline Lungs & $<0.5$ & $<0.5$ & $<0.5$ & $<0.5$ & $<0.5$ & $<0.5$ & 2.0 & $<0.5$ & 0.25 & $<0.5$ \\
\hline
\end{tabular}

$*=$ infectious virus titres (expressed in $\log _{10} \mathrm{TCID}_{50}$ ); refers to text for methods. $\mathrm{nc}=$ not collected. 


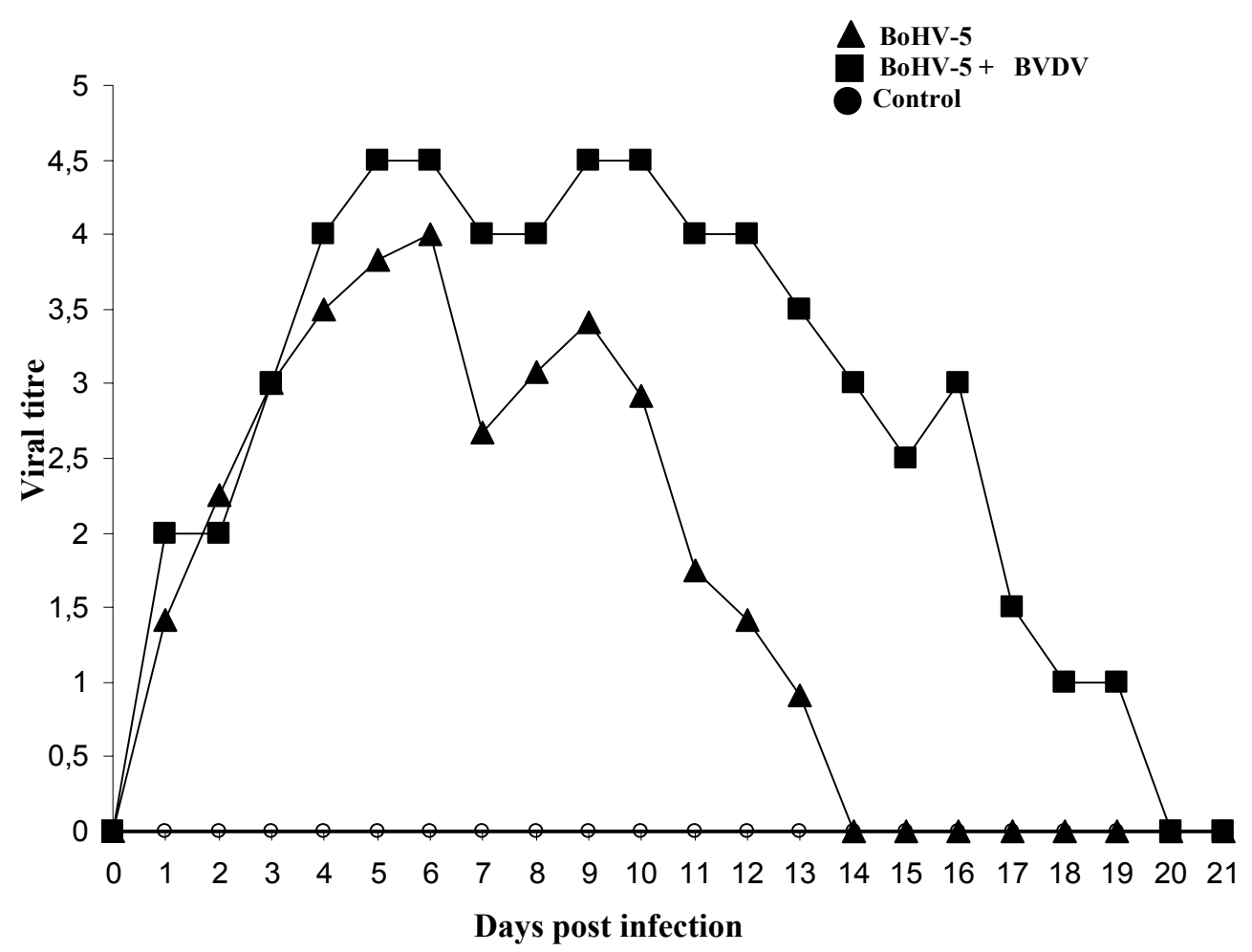

Figure 1. Nasal BoHV-5 shedding $\left(\log 10 \mathrm{TCID}_{50} / 50 \mu \mathrm{l}\right)$ in calves infected with BoHV-5 or co-infected with BVDV/BoHV-5.

In the group of calves co-infected with BoHV-5 and BVDV, BVDV was isolated from the lymphoid organs of died calves, to titres ranging from $10^{0.5}$ to $10^{3} \mathrm{TCID}_{50} / 50 \mu 1$ (Table 3).

Table 3. Infectious BVDV titres in lymphatic organs of calves co-infected with BoHV-5 and BVDV

\begin{tabular}{lcccc}
\hline \multirow{2}{*}{ Organ } & \multicolumn{4}{c}{ Calf identification } \\
\cline { 2 - 5 } & $\mathrm{A}$ & $\mathrm{B}$ & $\mathrm{C}$ & $\mathrm{D}$ \\
\hline Thymus & $\mathrm{nc}$ & $<0.5$ & 0.5 & $<0.5$ \\
$\begin{array}{l}\text { Retropharyngeal } \\
\text { lymphnodes }\end{array}$ & $3.0^{*}$ & $<0.5$ & 1.5 & $<0.5$ \\
$\begin{array}{l}\text { Mediastinic } \\
\text { lymphnodes }\end{array}$ & 2.0 & $<0.5$ & 1.0 & $<0.5$ \\
$\begin{array}{l}\text { Spleen } \\
\text { * infectious virus titres (expressed in } \log _{10}\end{array}$ & $\mathrm{TCID}_{50}$ ); refer to \\
text for methods. \\
nc $=$ not collected.
\end{tabular}

Arq. Bras. Med. Vet. Zootec., v.58, n.5, p.699-707, 2006

\section{DISCUSSION}

Previous inoculations of calves with BoHV-5 have shown that experimental reproduction of encephalitis is not straightforward (Meyer et al., 2001; Perez et al., 2002). Some authors suggested that an immunossupressive event might be necessary for the induction of overt clinical disease in cattle (Belknap et al., 1994; Cascio et al., 1999). As BVDV is a fairly ubiquitous agent of recognized immunossupressive capacity, it would not be unexpected to find BoHV-5 and BVDV coinfections under usual cattle farming conditions. In the present study, there were comparatively examined calves co-infected with BVDV and BoHV-5 and infected with BoHV-5. Two out of six calves only infected with BoHV-5 displayed clear signs of neurological disease. Such signs were less severe than those showed by coinfected calves. Thus, it seems that BVDV may 
have contributed to display of overt BoHV-5 disease. Co-infection with BoHV-1 and BVDV had also been shown to induce more severe illness when compared to infections only with BoHV-1 (Potgieter et al., 1984). In addition, it is well documented that BVDV infections can potentiate BoHV-1 infections in nature, thus enhancing the severity of clinical disease and lesions (Greig et al.1981).

Unfortunately, it was not possible to precisely determine the amount of BVDV present in the viral inoculum, since the source of virus was a batch of inadvertently contaminated cells. However, the amount of infectious virus necessary to induce infection is not clearcut. Even infectious titres, as low as $10 \mathrm{TCID}_{50}$, may be sufficient to cause viremia under experimental conditions. Even though it was not possible to determine the precise amount of infectious virus inoculated, calves were clearly infected, as judged by the induction of BVDV-specific neutralizing antibodies (Ficken et al., 1996).

The clinical, pathological and virological findings of the described experiment were largely similar to those reported in BoHV-5 field outbreaks of (Colodel et al., 2002; Salvador et al., 1998; D’Offay et al., 1993). According to the results, BVDV infections play an important role in increasing the severity of BoHV-5 disease. As BVDV infections are widespread in cattle populations, it seems that this virus may also be related to the outcome of BoHV-5 infections in the field.

\section{REFERENCES}

AMES, T.R. The causative agent of BVD: its epidemiology and pathogenesis. Vet. Med. v.81, p.848-869, 1986 .

BAGUST, T.J.; CLARK, L. Pathogenesis of meningoencephalitis produced in calves by infectious bovine rhinotracheitis herpesvirus. $J$. Comp. Pathol., v.82, p.375-382, 1972.

BELKNAP; E.B.; COLLINS, J.K.; AYERS, V.K. et al. Experimental infection of neonatal calves with neurovirulent bovine herpesvirus type 1.3. Vet. Pathol., v.31, p.358-365, 1994.

CARRILLO B.J.; AMBROGI A; SCHUDEL A.A. et al. Meningoencephalitis caused by IBR virus in calves in Argentina. Zentralbl. Veterinärmed., Reihe B, v.30, p.327-332, 1983.

CASCIO, K.L:, BELKNAP, E.B.; SCHULTHEISS, P.C. et al. Encephalitis induced by BHV5 and protection by prior vaccination or infection with BHV1. J. Vet. Diag. Invest., v.11, p.134-139, 1999.

COLODEL, E.M.; NAKAZATO, L.; WEIBLEN, R. et al. Meningoencefalite necrosante em bovinos causada por herpesvírus bovino no estado de Mato Grosso, Brasil. Ciên. Rural, v.32, p.293-298, 2002.

CORIA, M.F.; McCLURKIN, A.W. Specific immune tolerance in an apparently healthy null persistently infected with BVD virus. J. Am. Vet. Med. Assoc., v.172, p.449-451, 1978.

CORIA, M.F.; McCLURKIN, A.W; BOLIN, S.R. Total protein and immunoglobulins G1, G2, and $M$ in serum of calves persistently infected with bovine viral diarrhea virus. Am. J. Vet. Res., v.44, p.1938-1939., 1983.

D'OFFAY, J.M.; MOCK, R.E.; FULTON, R.W. Isolation and characterization of encephalitic bovine herpesvirus type 1 from cattle in North America. Am. J. Vet. Res., v.54,p. 534-539, 1993

EDWARDS, S., ROEDER, P.L. Attempted reactivation of latent bovine herpesvirus 1 infection in calves by infection with ruminant pestiviruses. Vet. Microb., v.8, p.563-569, 1983.

FICKEN, M.; JEEVAERATHNAM, S; WAN WELCH, S.K. et al. BVDV fetal infection with selected isolates. INTERNATIONAL SYMPOSIUM ON BOVINE VIRAL DIARHEA VIRUS-50 YEAR REVIEW. 1996 Cornell University, 1996. p.110-111.

FLORES, E.F.; DONIS, R.O. Isolation of a mutant MDBK cell line resistant to bovine viral diarrhea virus infection due to a block in viral entry. Virology, v.208, p.565-575, 1995.

GREIG; A., GIBSON; I.R., NETTLETON, P.F. et al. Disease outbreak in calves caused by a mixed infection with infectious bovine rhinotracheitis virus and bovine virus diarrhoea virus. Vet. Rec., v.108, p.480, 1981.

HOUSE, J.A.; BAKER, J.A. Bovine herpesvirus IBR-IPV. The antibody virus neutralization reaction. Cornell Vet.,v 61, p.320-335, 1971. 
LAMBOT, M.; HANON, E.; LECOMTE, C. et al. Bovine viral diarrhea virus induces apoptosis in blood mononuclear cells by a mechanism largely dependent on monocytes. J. Gen. Virol., v.79, p.1745-1749, 1988.

MEYER, G.;LEMAIRE, M.; ROS, C. et al. Comparative pathogenesis of acute and latent infections of calves with bovine herpesvirus type1 and 5. Arch. Virol., v.146, p.633-652, 2001.

NETTLETON, P.F; ENTRICAN. G. Ruminant pestiviruses. Br. Vet. J., v.151, p.615-643, 1995.

OLIVEIRA, L.G.; OLIVEIRA, E.A.S; SILVA, L.H.T. et al. Presença de pestivirus e anticorpos contra pestivirus em soros e cultivos celulares. Arq. Bras. Med. Vet. Zootec., v.48, p.513-521, 1996

PATON; D., SANDS, J.; ROEHE, P.M. BVD monoclonal antibodies: relationship between viral protein specificity and viral strain specificity by peroxidase linked assay. Arch. Virol., Suppl.3, p.47-54, 1991.

PEREZ, S.E; BRETSCHNEIDER, G; LEUNDA, M.R. et al. Primary infection, latency, and reactivation of bovine herpesvirus type 5 in the bovine nervous system. Vet. Pathol. v.39, p.437444, 2002.

POTGIETER, L.N.D., McCRACKEN, M.D.Hopvins,FM et al. Experimental production of bovine respiratory tract disease with bovine viral diarrhea virus. Am. J. Vet. Res., v.45, p.1582-1585, 1984.

RIET-CORREA, E.; VIDOR, T.; SCHILD, A.L.et al Meningoencefalite e necrose do córtex cerebral em bovinos causada por herpesvirus bovino-1. Pesq. Vet. Bras., v.9, p.13-16, 1989.

ROEHE P.M;. SILVA T.C.; NARDI, N.B. et al. Diferenciação entre os vírus da rinotraqueíte bovina infecciosa (BHV-1) e herpesvírus da encefalite bovina (BHV-5) com anticorpos monoclonais. Pesq. Vet. Bras. v.17, p.41-44, 1997.

ROEHE, P.M.; EDWARDS, S.; IBATA, G. Comparison of pestivirus multiplication in cells of different species origin. Res. Vet. Sci., v.57, p.210-214, 1994.

SALVADOR; S.C., LEMOS, R.A.A.; RIETCORREA, F. et al. Meningoencefalite em bovinos causada por herpesvirus bovino-5 no Mato Grosso do Sul e São Paulo. Pesq. Vet. Bras., v.18, p.76-83, 1998.

SOUZA, V.F; MELO, S.V; ESTEVES, P.A. et al. Caracterização de herpesvírus bovinos tipos 1 (BHV-1) e 5 (BHV-5) com anticorpos monoclonais. Pesq. Vet. Bras., v.22, p.13-18, 2002.

USER'S guide. Release 11.State College, Pensylvania: Miniteb, 1996. 